\title{
The Massive Fluvial Channel System in The Balam Graben: New Insight and Future Expectation from Menggala Formation in The Northern Rokan Block, Central Sumatera Basin
}

\author{
Iqbal Fardiansyah*, Agung Wiyono, Abdullah Faisal Talib \\ PT. Chevron Pacific Indonesia \\ Asia Afrika St. No.2, Jakarta 10270, Indonesia \\ *E-mail: mailto:iqbalfardiansyah@chevron.com
}

Article received: 8 July 2021, revised: 30 August 2021, accepted: 30 August 2021

DOI: $10.51835 /$ iagij.2021.1.2.34

\begin{abstract}
Menggala Formation has been long recognized as high-quality oil bearing sand and favorable reservoir in Central Sumatera Basin (CSB). Regionally, this formation is unique in characteristic, distribution and has not been thoroughly evaluated during early exploration and development. This paper aims to explain elaborately the new stratigraphic feature and regional paleogeography model of Menggala Formation throughout Balam grabens by integrating cores, biostratigraphy, water salinity, well $\log$ and 2D seismic image to better understand regional stratigraphic play concept. Lower Menggala Formation in the northern Rokan Block has been identified as the large scale of fluvial channel system that deposited parallel with Paleogene border fault remnants during early post-rift phase (22-25 million years ago). The fluvial channel belt is characterized by 4 to $5 \mathrm{~km}$ width, thick multi stacking fluvial sequence in the north and gradually change into river mouth sediment in the south. These sediments accumulated in depression area and also proven as huge productive reservoir in many fields. The north-south trending channel axis and geo-bodies confirmed by paleo bathymetric zonation, water salinity and 2D seismic image. The new paleogeography model helps better understanding of the regional stratigraphic concept of Menggala Formation across Balam grabens. In addition, this conceptual model also leads to strengthen the future exploration and development play concept within study area in Rokan Block.
\end{abstract}

Keywords: Rokan Block, Menggala Formation, fluvial channel system, paleogeography

\section{INTRODUCTION}

The area of study covers the Balam Graben, Central Sumatra Basin (CSB) which have $70 \mathrm{~km}$ length by $10 \mathrm{~km}$ width with NNW trending graben [1]. The Menggala Formation is part of Lower Sihapas Group deposited during early post rift. The Sihapas group generally characterized by thick sediment, with predominantly quartz sandstone, which is widely distributed across the CSB [2].

The Lower Menggala Formation as discussed in this paper was interpreted as a regional scale of massive fluvial systems drainage along Balam Graben remnant from the Malayan Shield and change into intertidal system to the south [3]. Thick Menggala fluvial sequence has been proven to contribute hydrocarbon accumulation in many fields, more than twenty oil fields have been discovered with approximately more than 4 $\mathrm{BBO}$ oil in place in this sub-basin [1]. By incorporating more additional data in Balam Graben, further updates of paleogeography model can be developed.

\section{REGIONAL TECTONICS}

CSB is mostly associated with fault block compartmentalization, transtensional to 
transpressional system, compressional folding and uplift [4]. The tectonostratigraphic events were grouped into four phases: 1) Pre-Rift Phase (F0) in Late Paleozoic to Mesozoic which formed the basin's basement; 2) SynRift Phase (F1) in the Eocene to Oligocene during an extensional syn-rift regime; 3) PostRift Phase (F2) in the Early to Middle Miocene with basin sagging regime; and 4) Uplifting and Inversion Phase (F3) in the Late Miocene to recent during a compressional regime [5].

The Balam graben has been divided into 3 sub-grabens (Figure 1): North Balam Graben, Central Balam Graben and Rangau Graben [1]. The north Balam Graben has NW-SE trend bounded by Jakun border fault in the west and Antara Accomodation Zone (ANAZ) in the south.

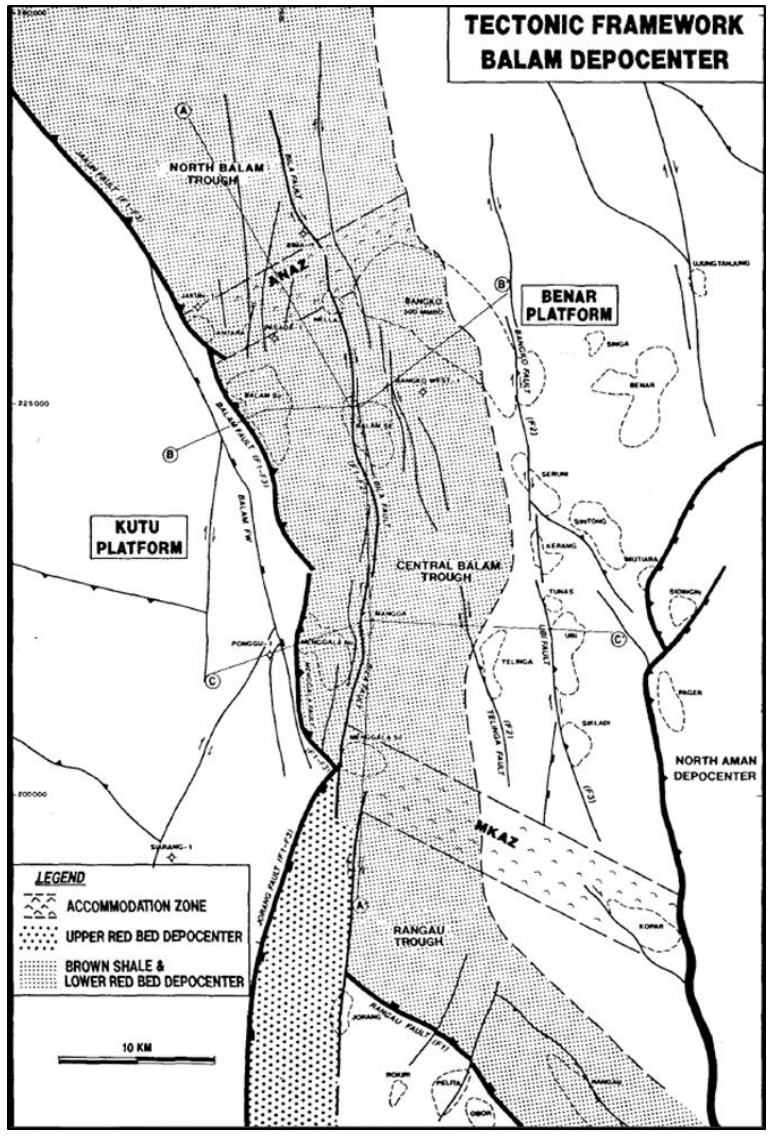

Figure 1. Tectonic framework of Balam Graben [1].

The northern graben actually linked to the Central Balam Graben through Jakun Fault.
The central graben bounded by BalamManggala Border Fault with N-S trend. This graben is also deeper compared to north Balam due to full graben system which involved ANAZ as north boundary during the earliest Post-Rift Phase (Late F1 to F2). This episode was characterized by depression and sagging north-south Paleogene border fault, reactivation of northwest trending right lateral strike slip (transpression /transtension) in the west of Bila Fault controlled the deposition of Menggala Formation (Figure 1). The South Balam Graben linked to Rangau Graben that was bounded by Menggala-Kopar Accomodation Zone (MKAZ) in the north and Manggala Border fault in the western border with NW-SE trending graben [1].

\section{NEOGENE CSB STRATIGRAPHY}

In the early Post-Rift Phase (F2), the Lower Sihapas Group was deposited unconformably over the Pematang Group by the deposition of Menggala Formation, marking Neogene sedimentation in the basin. The Menggala deposition occurred during the Lower Early Miocene. This thick sandstone package characterized by fine to coarse grain sandstones with pebble conglomerates, local tuffaceous and coal horizons and subordinate shales of fluvial to deltaic origin [6]. The Lower Menggala Formation deposition happened only along the basin center, and it is not occurred in the basement high or high morphology.

The Upper Sihapas Group deposition initiated and were dominated by marine sediments [6]. Bekasap and Bangko Formations were deposited, generally characterized by a thinning-upward sandstone package in a shallow marine environment. The number of sandstone layers recognized from different fields changes across the basin, which 
probably reflects pronounced shifts of deposition in this low accommodation, distal shelf setting [7]. Seismic exploration in the center of the CSB later revealed that the Upper Sihapas Group represent a braided river system and delta [6]. Internally, individual reservoirs contain a variety of facies, including pebble conglomerate beds, sandstone with wellpreserved internal depositional stratification, intensely bioturbated intervals with variably restricted and open marine trace fossil suites, and glaucony-bearing sandstone. Menggala, Bekasap and Bangko Formation sandstones of the Sihapas Group are well known as the main reservoirs of many prolific oil fields in CSB [7].

Duri Formation was deposited conformably above the Bekasap Formation with the same character of the overlying formation. The Duri Formation sand is only distributed in the northern part of Rokan Block as sea level retreated to northeast direction [8].

The Telisa Formation was deposited conformably above the Sihapas Group with monotonous brownish grey and calcareous shale, thin glauconitic sandstones, siltstones, and limestones, deposited in an open marine environment, marking the maximum transgression $[1,6,9]$. This unit has a regional distribution over the entire CSB and represents further marine transgression with the reduction of the sedimentary source areas [6].

Petani Formation, which was deposited unconformably above the Telisa Formation. The base of Petani Formation marks the end of a long transgressive period in CSB [10]. This formation was deposited during the Uplifting and Inversion Phase (F3) as regional sag slowed down with regressive cycle which is characterized by greenish grey shales and intermittent sand interbeds [4] (Figure 2).

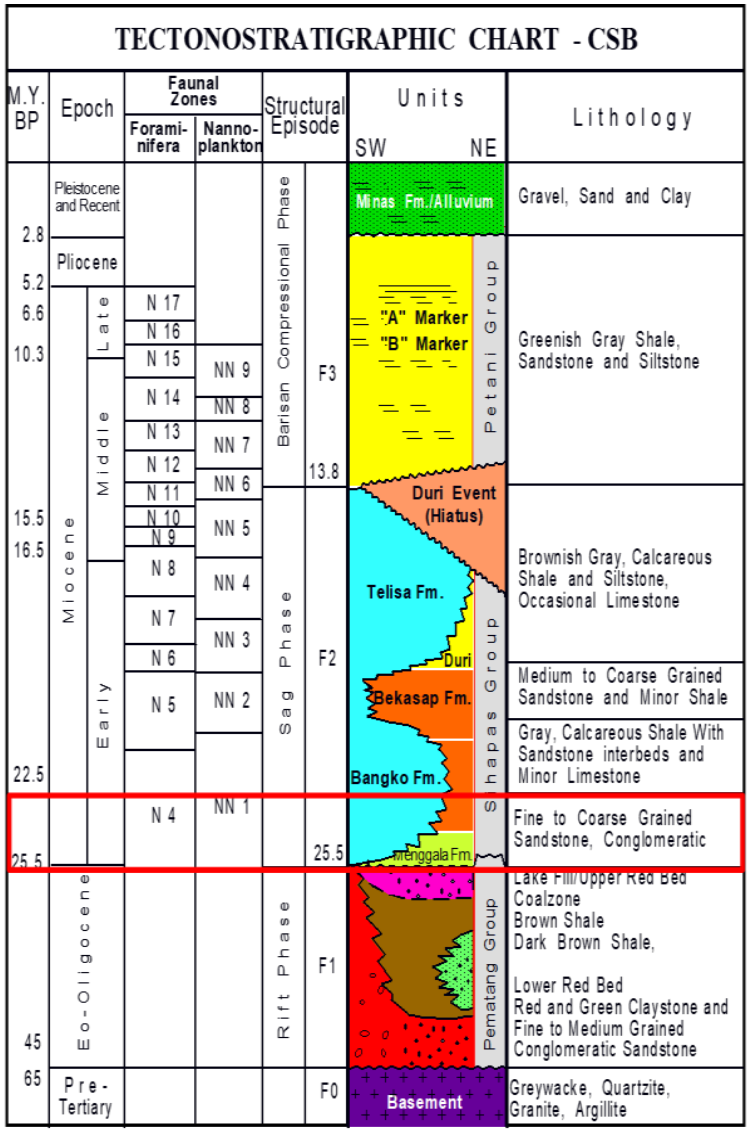

Figure 2. Regional stratigraphy, tectonostratigraphic and the biostratigraphic zonation in CSB. The Menggala Formation is highlighted in red box [11].

\section{DATA AND METHOD}

This following paragraph described methods that have been utilized and implemented in this study. Starting with A literature review of the latest publications and studies of paleogeography in the area of Sumatera, especially as related to Menggala Formation in Central Sumatera Basin. Follow by reconstructing regional chronostratigraphic framework by updating previous exploratory well marker picks based on biostratigraphic data (22 to $25.5 \mathrm{Ma}$ ) by [12] and extending the interpretation into 8 key fields in the Balam Graben including Bima Strat, Nella, Balam SE, Mangga, Menggala North, Menggala South, Jorang and Rokiri. Some key regional 2D seismic sections in the Balam Graben also have been reviewed to identified geometry and 
distribution of Menggala Channel. The existing depositional facies interpretation and biostratigraphy data in Balam Graben has been also integrated to strengthen the paleobathymetry interpretation.

\section{Early Miocene Sumatra Paleogeography}

Tectonically, The Tertiary Basins in Sumatra lies on the western margin of Sundaland. The Sumatra Basins initially formed as back-arc basin by the emergence of the Barisan Mountains in the Late Oligocene. In the Earliest Miocene, the Mountains were restricted by sea and the regional sagging submergence the Barisan Mountain create deepening the fore arc and back arch basin. This also create embayment and narrow coastal morphology in Central Sumatera and opening sea to South Sumatera. Regional transgression also continued until Middle Miocene. The Barisan Mountains provided one of the sediment sources and the main provenance derive from Malayan shield [13]. Different stratrigraphic member of Sihapas Group have been recognized in southwest to northeast from Barisan Mountains [2].

In the Early Miocene, the river systems drainage from the uplands of the Malay Peninsula to the CSB [3]. These river systems deliver fluvial-deltaic influx that prograde into basin center of CSB $[7,8,9]$. CSB formed as a narrow seaway in the south and uplands in the northern area during Earliest Miocene [3,13], The CSB tend to shallower compared to the North and South Sumatra Basins. Sumatra paleogeography reconstruction shows bathymetric depth increasing to the North and South Sumatra Basins, which corresponds to extensive Miocene carbonate development in both basin $[3,6]$. In the CSB, in situ carbonate was not extensively growth due to high clastic sediment influx from the Malayan Shield and Barisan Mountains [2,3,6] (Figure 3).

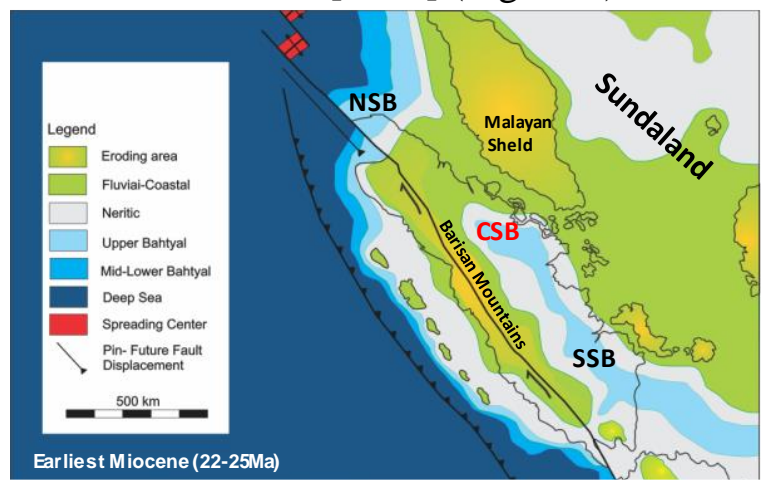

Figure 3. Sundaland paleogeography during the Early Miocene. Earliest Miocene (25 - $22 \mathrm{Ma})$ equivalent to Menggala time deposition [13].

\section{Earliest Miocene of Menggala Fluvial Paleogeography in Balam Graben}

The regional paleogeography is built by the reconstruction of the 'Lower' Early Miocene Stage (22-25 Ma) which corresponds to the Menggala Formation deposition using integration core log facies, biostratigraphy and 2D seismic. The Menggala formation is clearly identified in some field within Balam Graben; Pinang, Bima strat, Balam SE, Mangga Menggala North, Menggala South, and Jorang, which most of those fields located along the Balam Depocenter. Early (F2) phase is a transition of Paleogene rifting to Early Miocene Sagging that create depression, accommodation space in the basin center and erosion along border fault [1]. At this time, the Menggala Formation in the Balam Graben potentially formed as syntectonic sediment of fluvial system controlled by deformation of Jakun-Balam-Rangau border fault in the west, activation of Nella and Bila right lateral strike slip fault in the east, and low paleomorphology in between. The Bila-Nella fault also significantly control high and low morphology for Menggala deposition due to transpresion and transtension system. 
In general, Balam Graben has been subdivided into 3 regions based on graben framework: 1) the North Balam Graben; 2) the Central Balam Graben; and 3) the Rangau Graben [14]. This sub regions will help to illustrate how paleoenvironment and its geometry changes throughout the depositional and tectonic regions which will be discussed further in following paragraphs.

Menggala Formation in North Balam Graben has been observed from Northern Bima-Strat and Pinang area. Biostratigrapy data confirmed that Menggala sand is barren of foram. Existence of pollen data (e.g. $S$. moriformis) distinctively indicate that this formation deposited in terrestrial to supratidal environment that linked to fluvial system. The formation water salinity ranges from 800 to $1200 \mathrm{ppm}$ and also confirm freshwater environment. The fluvial channel belt and incised valley system can be clearly observed from NE-SW Regional seismic section. The channel belt width was predicted 2-3 km with individual stacking channel across the belt. The channel belt is slightly narrow and getting wider heading to southern basin. The Menggala Formation in the northern area have excellent sand quality and proven for productive reservoir in Pinang field.

In Central Balam Graben, Menggala Formation is observed in Balam SE, Mangga and Menggala North area. 2D Seismic section and well data indicated this formation is thicker and wider compared to the North Balam Graben. In this area, the Menggala main channel belt is very well developed in the west of Bila Fault due to depression during transition of late F1 to early F2 tectonic phase. In the eastern side of Bila fault the sand formation was not deposited, as it can be observed in some wells in the eastern part of Balam SE. The channel belt complex is predicted getting wider (approximately 4-5 $\mathrm{km}$ ) with gross thickness over $270 \mathrm{ft}$ that thinning and pinch out to the border fault, high morphology and continue distributed to Mangga and Menggala North area. Biostratigraphy information still confirm the barren of planktonic foram and slightly appear benthonic foram in Central Balam Graben which strongly indicate fluvial has been influenced by intertidal environment. Water salinity showing increase from north (1400 $\mathrm{ppm})$ to the south area $(1800 \mathrm{ppm})$ that indicates transition from freshwater to brackish environment. These Menggala channels has proven to contribute significant oil production and stratigraphic play target in this area (Figure 4).

The South Balam Graben tectonically linked to Rangau Graben [1]. In the southern Balam Graben, The Menggala sand can be recognized from Menggala South, Ubi-Sikladi and Jorang field. The existence of bentonic foram (S.cf.delpix, S.cf.ciperoensis, Z.cf.bujigatus) and slightly calcareous content from core data indicate the Menggala channel has been transformed into intertidal environment as estuary river mouth with tidal channel, tidal bar and tidal flat facies. This is also confirmed by formation water salinity ranges from 1800 to $2000 \mathrm{ppm}$ indicate the brackish environment. The channel shape has not clearly identified from seismic image due to change of depositional setting. The sand width has been estimate distributed up to 10 $\mathrm{km}$ to the west and east following the migration of estuary. In this area, the Menggala sand also proven as productive reservoir in those observation field. 

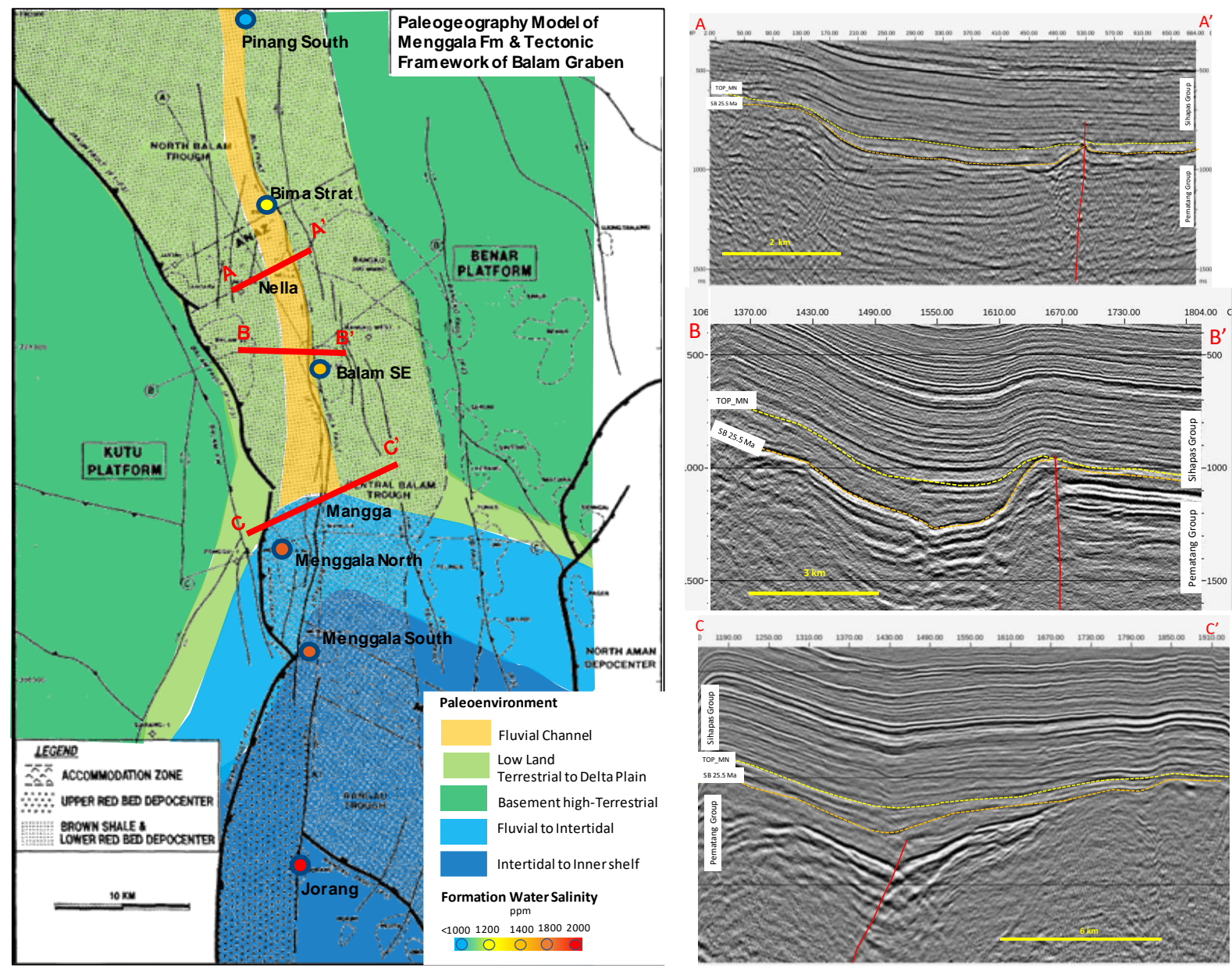

Figure 4. Menggala Paleogeography interpretation overlain by tectonic framework, updated and modified from [1] (left), the channel belt complex has been recognized by several 2D seismic crossing Balam Graben, yellow dash horizon is Top Menggala Fm and orange dash horizon is SB 25.5 equivalent to top Pematang Fm (right).

\section{RESULT AND DISCUSSION}

The Menggala paleogeography model has improved current understanding and given the insight of the depositional model in the earliest post rift phase in corresponding to the reservoir geometry, new play type and reservoir quality within existing fields in the Balam Graben. The tectonostratigraphy of the Balam Graben has been better explain in the previous study [1]. However, it has not elaborated the detail paleogeography of early post rift of Menggala Formation. The study also mentions about the transition time from rifting to Early Miocene sagging with wrenching fault during F2 period that creating accommodation space for
Menggala deposition that supported the current interpretation.

The new paleogeography model of Menggala Formation also helps to provide better explanation for Menggala stratigraphic play, physical reservoir characteristics, reservoir quality and its lateral distribution observed in the existing field. Several additional detailed observations have been useful for shaping exploration plan, delineating area with potential stratigraphic play, identify sweet spots for future wells, as well as to answer some post drill questions and reasoning of good and less successful wells in the past. 


\section{CONCLUSIONS}

The Earliest Miocene of Balam Graben interpreted as a terrestrial in northern basin, that gradually change to marine embayment with high shoreline curvature and open sea setting in the south. General depositional system of the Earliest post rift in Balam Graben is interpreted as fluvial system to estuary intertidal environment that controlled by Late Oligocene morphology and Paleogene structural remnants. The fluvial channel shape has been well recognized along western Bila Fault from the northern and central area with channel width 2 to $3 \mathrm{~km}$ (channel belt $3-4 \mathrm{~km}$ ), in the southern area the channel shape was getting wider and unrecognized very well due to change of depositional environment to estuary system. Biostratigraphy data confirm that barren of foram in the northern field area and shallow marine foram appear in southern area, that indicate change of depositional environment. Formation water salinity and calcareous content from core data has validated the paleogeographic interpretations. Fresh water salinity and non-calcareous mineral content from core data were observed in the northern graben, meanwhile brackish water salinity and calcareous content has been recognized from central to south of graben. Generally, the increase of salinity and calcareous content from north to the south direction align with depositional setting. Menggala Formation has proven to produce significant hydrocarbon in the Central and Southern Balam Graben. Current understanding of new paleogeography model, combined with analog data from existing field will guide to find new exploration play type concept, i.e. new opportunity along Bila Fault. Current 2D seismic image is unable to clearly visualize and illustrate the full geometry of Menggala channel and structure along Bila fault. This paleogeography model can help to guide further 3D seismic acquisition program in Balam Graben.

\section{ACKNOWLEDGEMENT}

Authors would like to express sincere gratitude to SKKMigas and PT Chevron Pacific Indonesia management, ARM-Earth Science and Exploration Teams for the supports on publication of this paper. We thank all of our Chevron's colleagues who support the paper preparation: Muhammad Fachreza, Faizal Al-Marawi and Muhammad Arsyid. We also would like to acknowledge previous workers and former Chevron's Senior Earth Scientists in Central Sumatra Basin whom their fine and exceptional works provided strong foundations for this paper: Yarmanto, Karsani Aulia, Tom.L. Heidrick, Darwin Kadar, Ukat Sukanta, Habash Semimbar and Bob Morley.

\section{REFERENCES}

1. Yarmanto; Heidrick, T. L.; Indrawardana; and Strong, B. L.; Tertiary Tectonostratigraphy Development of Balam Depocenter, Central Sumatra Basin Indonesia, In the $24^{\text {th }}$ Annual Convention Proceeding of Indonesian Petroleum Association, 1995, 35-45.

2. Cameron, N. R.; The Stratigraphy of the Sihapas Formation in the North West of the Central Sumatra Basin, In the $12^{\text {th }}$ Annual Convention Proceeding of Indonesian Petroleum Association, Jakarta, May 1983, 1, 43-65.

3. Morley, R. J.; Morley, HP.; and Swiecicki, T.; Mio-Pliocene Palaeogeography, Uplands and River Systems of the Sunda Region Based on Mapping within a Framework of Vim Depositional Cycles, In the $40^{\text {th }}$ Annual Convention Proceeding of Indonesian Petroleum Association, Jakarta, May 2016.

4. Mertosono, S. and Nayoan, G. A. S.; The Tertiary Basinal Area of Central Sumatra, In the $3^{\text {rd }}$ Annual Convention Proceeding of Indonesian Petroleum Association, 1974, 63-76.

5. Heidrick, T. L. and Aulia, K. A.; Structural and Tectonic Model of the Coastal Plains Block, Central Sumatra Basin, Indonesia. In the $22^{\text {nd }}$ Annual Convention Proceeding of Indonesian Petroleum Association, Jakarta, May 1981. 
6. De Smet, M. E. M. and Barber, A. J.; Tertiary Stratigraphy. Geological Society, London, Memoirs. 2005, 31, 1, 86-97.

7. Willis B.J. and Fitris, F.; Sequence Stratigraphy of Tide-Influenced Reservoir Sandstones in Minas Field, Indonesia. Journal of Sedimentary Research. 2012, 82, 6, 400-421.

8. Wongsosantikno, A.; Lower Miocene Duri Formation Sands, Central Sumatra Basin, In the $5^{\text {th }}$ Annual Convention Proceeding of Indonesian Petroleum Association, Jakarta, 1976.

9. De Coster, G. L.; The Geology of the Central and South Sumatra Basins, In the $3^{\text {rd }}$ Annual Convention Proceeding of Indonesian Petroleum Association, 1974, p 77 -110.

10. Suryanto, U. and Wycherly, WA.; A high resolution seismic stratigraphy study, central
Sumatra basin Indonesia, In the $13^{\text {th }}$ Annual Convention Proceeding of Indonesian Petroleum Association, 1984, p 281 -300.

11. Mertani, B.; Heidrick, T.; and Yarmanto, A.; Petroleum Geology of Indonesian Basins 2, 1996.

12. Sukanta, U.; Yarmanto, A.; and Kadar, D.; Regional Sequence Stratigraphy Correlation Central Sumatra Basin. Caltex Pacific Indonesia Internal Report, Rumbai, Riau, 1997.

13. Barber. A. J.; Crow. M. J.; and Milsom, J. S.; Sumatra: Geology, Resource and Tectonic Evolution, Geological Society, London, 2005, Memoirs 31.

14. Yarmanto; Noeradi, D.; and Hendar; Telisa Depositional Model in the Central Sumatra Basin, In the $34^{\text {th }}$ Annual Convention Proceeding of Indonesian Petroleum Association, Jakarta, 2010. 